\title{
Optimisation of Anthocyanin Extraction from Purple Pitaya and Verification of Antioxidant Properties, Antiproliferative Activity and Macrophage Proliferation Activity
}

\author{
Xi Yang ${ }^{1}$, Yingnan Yang ${ }^{2}$, Min Shi ${ }^{2}$, Yuepeng Wang ${ }^{2}$, Zhenya Zhang ${ }^{2} \&$ Yifeng $\mathrm{Lu}^{1}$ \\ ${ }^{1}$ School of Life Sciences, Yunnan University, Kunming, China \\ ${ }^{2}$ School of Life and Environmental Science, University of Tsukuba, Tsukuba, Ibaraki, Japan \\ Correspondence: Yifeng Lu, School of Life Sciences, Yunnan University, No. 52 Green Lake North Road, \\ Kunming 650000, China. Tel: 86-133-8884-8518. E-mail: lyftoday@126.com
}

Received: March 2, 2013 Accepted: April 9, 2013 Online Published: April 23, 2013

doi:10.5539/ijb.v5n3p19

URL: http://dx.doi.org/10.5539/ijb.v5n3p19

\begin{abstract}
To separate and purify anthocyanins from purple pitaya (H. polyrhizus) with SP825 resin, the adsorption properties of the SP825 resin were evaluated by static and dynamic experiments with respect to the following parameters: $\mathrm{pH}$, temperature, dilution multiple of the sample solution and concentration of the ethanol eluting agent. The data from the static experiments were fitted to the pseudo-second-order kinetics model $\left(\mathrm{R}^{2}=0.9919\right)$ and Freundlich isotherm model $\left(\mathrm{R}^{2}=0.9672\right)$. A total of $658 \mathrm{mg}$ of anthocyanins were contained in $1000 \mathrm{~g}$ of $H$. polyrhizus fresh fruits (both peel and pulp), which could be made into $1.5 \mathrm{~g}$ of anthocyanin-rich extract from $H$. polyrhizus (AEHP) containing $520 \mathrm{mg}$ of anthocyanins. Overall, $79 \%$ of the anthocyanins were extracted. The AEHP showed strong DPPH radical scavenging activity, ABTS radical scavenging activity, hydroxyl radical scavenging activity, reducing power, ferrous metal ion chelating ability and SOD-like activity. Moreover, the AEHP inhibited the proliferation of the human colorectal cancer cell line DLD-1 and accelerated the growth of macrophage cells. Finally, the AEHP was proven to have a high tinctorial power and physiological and health functions.
\end{abstract}

Keywords: purple pitaya, anthocyanins, resin, antioxidant properties, antiproliferative activity, macrophage Proliferation activity

\section{Introduction}

Edible colorants include natural and synthetic colorants. Because synthetic colorants have toxic effects on humans, natural colorants have drawn more attention (Chou et al., 2007). Based on the chemical structure, natural colorants have been classified into tetrapyrroles, carotenoids, polyphenolic compounds, and alkaloids. As a type of phenolic compound, anthocyanins are plant pigments that are widely distributed in nature (Benoit, 2004; Wu \& Prior, 2005; Yang \& Zhai, 2010). Additionally, anthocyanins are considered to be food colorants and health food materials (Smith et al., 2000; Wang et al., 2000; Cooke et al., 2005; Pergola et al., 2006).

The pulp colour in Hylocereus fruits varies from white to red and purple. Hylocereus cacti (H. cacti) have red pulp, and Hylocereus polyrhizus (H. polyrhizus) have purple pulp. Hylocereus fruits might have a potential tinctorial power, and some researchers have studied the antioxidant and antiproliferative activities of $H$. cacti (Wu et al., 2006). The results revealed that the acetone extracts of $H$. cacti appeared to have certain DPPH and ABTS radical scavenging activities and to inhibit the growth of B16F10 melanoma cells. Moreover, the anticancer activities have been widely investigated in anthocyanin-rich extracts from the berry (Hogan et al., 2010). However, there is little information on the antioxidant and antiproliferative and macrophage proliferation properties of the AEHP with resin (Wang et al., 2008). Therefore, an efficient extraction method was warranted for testing. Using this method, we obtained an AEHP that had a high tinctorial power. Finally, the physiological and health functions of the AEHP were also evaluated by antioxidant, antiproliferative and macrophage proliferation activity assays. 


\section{Materials and Methods}

\subsection{Sample Preparation}

H. polyrhizus fruits (both peel and pulp) were collected in the summer from Yunnan Province, China. First, the fruits were juiced and stored under $-20^{\circ} \mathrm{C}$ for 2 months. Next, they were thawed at $25^{\circ} \mathrm{C}$, stirred and divided into $50 \mathrm{~g}$ portions. The samples were diluted, and the $\mathrm{pH}$ values were adjusted before they were filtered through 300 mesh gauze. Finally, diatomite powders were added at a ratio of 1.7 gram: 100 millilitres (diatomite powder: sample juice), and the mixtures were centrifuged for $5 \mathrm{~min}$ at $7000 \mathrm{r} / \mathrm{min}$ to collect the supernatant for testing.

\subsection{Resin Pretreatment}

The SP825 resin was soaked in 95\% ethanol, adopting the wet packing method, for $24 \mathrm{~h}$. The resin fully swelled, which removed the impurities, gas and floating resin debris. Then, the resin columns were washed with distilled water thoroughly (Fan et al., 2008).

\subsection{Static and Dynamic Adsorption / Desorption Tests}

\subsubsection{Static Adsorption / Desorption Tests}

First, $1 \mathrm{~g}$ of resin was placed in a tube with a lid. Next, the $\mathrm{pH}$ of the sample was adjusted from 1 to 9 with $0.1 \mathrm{M}$ hydrochloric acid. After adding $15 \mathrm{~mL}$ of the sample, the tubes were incubated at $25^{\circ} \mathrm{C}$ for $2 \mathrm{~h}$. Then, the sample was scanned between 400 and $750 \mathrm{~nm}$ (Shimadzu UV-1800). The absorbance values of the sample were measured at the maximum absorption wavelengths $\left(\lambda_{\max }\right)$. The tubes without resin were the controls. Finally, the optimum $\mathrm{pH}$ was evaluated according to the adsorption and degradation ratios as follows:

$$
\begin{gathered}
\text { Adsorption ratio }(\%)=\left(A_{\text {control }}-A\right) / A_{\text {sample }} \times 100 \% \\
\text { Degradation ratio }(\%)=1-A_{\text {control }} / A_{\text {sample }} \times 100 \%
\end{gathered}
$$

where A was the absorbance of the sample after adsorption for $2 \mathrm{~h}, \mathrm{~A}_{\text {sample }}$ was the initial sample absorbance, and $\mathrm{A}_{\text {control }}$ was the absorbance of the control sample after $2 \mathrm{~h}$.

A total of $1 \mathrm{~g}$ of resin was placed in a tube with a lid. Next, the $\mathrm{pH}$ of the sample was adjusted according to the static test results. After adding $15 \mathrm{~mL}$ of the sample, the tubes were incubated for $6 \mathrm{~h}$ at adsorption temperatures of $25,30,40,50$ and $60^{\circ} \mathrm{C}$. The absorbance values of the samples were measured at $\lambda_{\max }$. The tubes without resin were the controls. Finally, the optimum temperature was evaluated.

For the next test, $1 \mathrm{~g}$ of resin was placed in a triangular bottle with a cork. Next, the $\mathrm{pH}$ and temperature of the sample were adjusted according to the static test results. After adding $100 \mathrm{~mL}$ of the sample, the bottles were shaken for $16 \mathrm{~h}(180 \mathrm{r} / \mathrm{min})$. The bottles without resin were the controls, and the sampling interval was $0.5 \mathrm{~h}$. Then, the absorbance values were measured at $\lambda$ max to determine the anthocyanin concentrations in the adsorption process until equilibration. Finally, the kinetics curve was drawn according to the data.

A total of $0.1 \mathrm{~g}$ of resin was placed in a tube with a lid. Next, $10 \mathrm{~mL}$ of the sample, each containing a different concentration of anthocyanins, was added to the tube and shaken at $180 \mathrm{r} / \mathrm{min}$ for $8 \mathrm{~h}$ at $25^{\circ} \mathrm{C}$. The tubes without resin were the controls. Then, the absorbance values were measured at $\lambda_{\max }$ to determine the anthocyanin concentrations in the adsorption process until equilibration. Finally, an isotherm curve was drawn according to the data.

\subsubsection{Dynamic Adsorption / Desorption Tests}

Based on the static tests, the dynamic tests were investigated with respect to the following parameters: $\mathrm{pH}$, the dilution multiple of the sample and the concentration of the ethanol eluting agent. Adopting the wet packing method, the dynamic tests were conducted in a glass column packed with $18 \mathrm{~g}$ (dry height) of resin. The volume of the resin bed $(1.9 \mathrm{~cm} \times 13 \mathrm{~cm})$ was $37 \mathrm{~mL}$, and the ratio of its diameter to height was approximately 1:7. Second, the resin columns were pretreated and $50 \mathrm{~g}$ of sample was thawed and diluted. Then, the $\mathrm{pH}$ values were adjusted. Third, the samples were filtered through 300 mesh gauze, and diatomite powders were added at a ratio of 1.7 gram: 100 millilitres (diatomite powder: sample juice), and the mixtures were centrifuged. Next, the supernatant, $3 \mathrm{BV}$ (resin bed volume) distilled water and $3 \mathrm{BV}$ ethanol eluting agent were passed through the resin columns at $3 \mathrm{~mL} / \mathrm{min}$ in that order. The collected eluted liquid was rotated and evaporated for $90 \mathrm{~min}$ at $40{ }^{\circ} \mathrm{C}$ and freeze-dried into a powder. Finally, the anthocyanin concentrations of the powder were determined, and the optimum conditions were determined. 


\subsection{The Determinations of the Total Anthocyanin and Polyphenol Contents and E}

\subsubsection{The Determination of the Total Anthocyanin Content}

A total of $5 \mathrm{mg}$ of the AEHP powder was dissolved in $5 \%$ formic acid up to a volume of $100 \mathrm{~mL}$ in a volumetric flask. The solution was diluted five times and scanned to obtain a $\lambda_{\text {max }}$ between 500 and $550 \mathrm{~nm}$. Then, the absorbance was measured at $\lambda_{\text {max. }}$. Blueberry powders were used as a standard, and its anthocyanin content was $26.2 \%$.

$$
\text { The Anthocyanins Content of the Sample }=(A / B) 26.2 \%
$$

where A was the absorbance of the sample and $B$ was the absorbance of the standard sample.

\subsubsection{The Determination of the Phenolic Content}

The phenolic compounds were determined using the Folin-Ciocalteu method with some modifications (Mau, et al., 2002). The AEHP was completely dissolved in distilled water with a concentration of $2 \mathrm{mg} / \mathrm{mL}$. The solution $(0.125 \mathrm{~mL})$ was mixed with distilled water $(0.375 \mathrm{~mL})$ and $0.5 \mathrm{~mL}$ of the Folin-Ciocalteu reagent. After $3 \mathrm{~min}$, $0.5 \mathrm{~mL}$ of $\mathrm{Na}_{2} \mathrm{CO}_{3}(20 \%)$ was added, and the mixture was brought to a final volume of $5 \mathrm{~mL}$ with distilled water. After being kept in the dark for $90 \mathrm{~min}$, the O.D. of the mixture was read at $725 \mathrm{~nm}$.

\subsubsection{The Determination of the E of the AEHP by the CU Method}

The CU method is often used to represent the dyeing capability of a natural edible pigment. The CU is also known as the ratio of absorption value, i.e., the absorption value of $100 \mathrm{~mL}$ of a solution containing $1 \mathrm{~g}$ of pigment with a $1 \mathrm{~cm}$ optical path. In the actual detection process, the tested solution concentration often is not completely $1 \%$, and the optical path may not be exclusively $1 \mathrm{~cm}$ because of the solubility of the pigment and operational aspects. The measured pigment solution absorption value is different from the ratio of the absorption value. Therefore, the pigment solution absorption value needs to be transformed into the ratio of the absorption value. The method is as follows:

$$
E=E_{1} / C_{l} L_{1}
$$

where $E_{1}$ was the measured absorption value of the pigment solution, $C_{1}$ was the measured concentration of the pigment solution, $\mathrm{L}_{1}$ was the measured optical path of the pigment solution, $\mathrm{E}(\mathrm{CU})$ was the ratio of the absorption value of the pigment solution, $\mathrm{C}$ was the concentration of the pigment solution (1\%), and $\mathrm{L}$ was the optical path of the pigment solution $(1 \mathrm{~cm})$.

The AEHP was diluted to $0.01 \%$ with a citric acid disodium hydrogen phosphate buffer solution ( $\mathrm{pH} 3$ ).

$$
E=A /(0.01 \times 1)
$$

where $\mathrm{A}$ was the absorbance at $\lambda_{\max }$.

\subsection{Antioxidant Capacity of the Anthocyanin-Rich Extracts by the SP825 Resin}

Anthocyanin possesses anti-inflammatory and anti-carcinogenic activity, cardiovascular disease prevention, obesity control, and diabetes alleviation properties, all of which are more or less associated with their potent antioxidant property (He et al., 2010). Antioxidant capacity of the anthocyanin-rich extracts was assayed according to the following methods.

\subsubsection{DPPH Radical Scavenging Activity}

The DPPH radical scavenging activity of the AEHP was measured according to the method described by Blois (2002) with some modifications (Blois, 2002). Aliquots $(0.5 \mathrm{~mL})$ of the various concentrations $(0.039,0.078$, $0.156,0.313,0.625,1.250 \mathrm{mg} / \mathrm{mL})$ of the AEHP were mixed with $2 \mathrm{~mL}(25 \mu \mathrm{g} / \mathrm{mL})$ of a MeOH solution of $\mathrm{DPPH}$. Then, the mixture was shaken vigorously and allowed to stand in the dark for $30 \mathrm{~min}$. The absorbance was measured at $517 \mathrm{~nm}$ against a blank. A decrease in the DPPH solution absorbance indicated an increase in the DPPH radical-scavenging activity, which was calculated according to the following equation:

$$
D P P H \text { radical-scavenging activity }(\%)=\left[A_{0}-A_{1} / A_{0}\right] \times 100
$$

where $\mathrm{A}_{0}$ was the absorbance without the sample and $\mathrm{A}_{1}$ was the absorbance in the presence of the sample.

\subsubsection{ABTS Radical Scavenging Assay}

The ABTS was dissolved in distilled water at a final concentration of $7 \mathrm{mM}$ and mixed with a potassium persulphate solution at a final concentration of $2.45 \mathrm{mM}$. The reaction mixture was left to settle at room temperature for 12-16 $\mathrm{h}$ in the dark before use (Trishna et al., 2011). For each experiment, a freshly prepared $\mathrm{ABTS}^{+}$solution was diluted with $0.01 \mathrm{M}$ phosphate buffer saline (PBS, pH 7.4) to adjust its absorbance to within 
$0.70 \pm 0.02$ at $734 \mathrm{~nm}$. Then, $0.15 \mathrm{~mL}$ of the samples with different concentrations $(0.156-10.00 \mathrm{mg} / \mathrm{mL})$ was mixed with $2.85 \mathrm{~mL}$ of the $\mathrm{ABTS}^{+}$solution. Finally, the absorbances were measured at $734 \mathrm{~nm}$ after incubation at room temperature for $10 \mathrm{~min}$. The scavenging activity of the ABTS free radical was calculated using the following equation:

$$
\text { ABTS scavenging activity }(\%)=[(C-D)-(A-B) /(C-D)] \times 100
$$

where $\mathrm{A}=$ absorbance of ABTS solution + sample $/$ standard, $\mathrm{B}=$ absorbance of potassium persulphate + sample / standard, $\mathrm{C}=$ absorbance of ABTS solution + distilled water / methanol, and $\mathrm{D}=$ absorbance of potassium persulphate + distilled water / methanol.

\subsubsection{Hydroxyl Radical Scavenging Activity}

The $\mathrm{HO} \bullet$ scavenging activity was measured according to a literature protocol with a few modifications (Nicholas, et al, 1989). The $\mathrm{HO} \cdot$ was generated from $\mathrm{FeSO}_{4}$ and $\mathrm{H}_{2} \mathrm{O}_{2}$ and detected by its ability to hydroxylate salicylate. The reaction mixture $(2.5 \mathrm{~mL})$ contained $0.5 \mathrm{~mL}$ of $\mathrm{FeSO}_{4}(1.5 \mathrm{mM}), 0.35 \mathrm{~mL}$ of $\mathrm{H}_{2} \mathrm{O}_{2}(6 \mathrm{mM}), 0.15 \mathrm{~mL}$ of sodium salicylate $(20 \mathrm{mM})$ and $1 \mathrm{~mL}$ of the AEHP solution at different concentrations. Ascorbic acid was used as the positive control. After incubation for $1 \mathrm{~h}$ at $37^{\circ} \mathrm{C}$, the absorbance of the hydroxylated salicylate complex was measured at $562 \mathrm{~nm}$. The percentage scavenging effect was calculated as:

$$
\% H O \cdot \text { scavenged }=\left[1-\left(A_{1}-A_{2}\right) / A_{0}\right] \times 100 \%
$$

where $\mathrm{A}_{1}$ was the absorbance of the sample or ascorbic acid, $\mathrm{A}_{0}$ was the absorbance of the solvent control, and $\mathrm{A}_{2}$ was the absorbance of the reagent blank without sodium salicylate.

\subsubsection{Reducing Power}

The reducing power of the AEHP was measured according to the method of Yen and Chen (1995) with slight modifications (Yen et al, 1995). An aliquot of each sample $(1 \mathrm{~mL})$, with different concentrations, was mixed with $1 \mathrm{~mL}$ of phosphate buffer $\left(200 \mathrm{mM}, \mathrm{pH}\right.$ 6.6) followed by $1 \mathrm{~mL}$ of $1 \%$ potassium ferricyanide $\left(\mathrm{K}_{3} \mathrm{Fe}[\mathrm{CN}]_{6}\right)$. The mixture was incubated for $20 \mathrm{~min}$ in a water bath at $50^{\circ} \mathrm{C}$. After incubation, $1 \mathrm{~mL}$ of $1 \%$ trichloroacetic acid (TCA) was added. After straining, $2 \mathrm{~mL}$ of the sample solution from before was mixed with $2 \mathrm{~mL}$ of distilled water and $0.4 \mathrm{~mL}$ of $0.1 \%$ ferric chloride $\left(\mathrm{FeCl}_{3}\right)$, and then the absorbance was measured at $700 \mathrm{~nm}$ against a blank in the spectrophotometer. A higher absorbance indicates a higher reducing power activity. Ascorbic acid was used as the positive control.

\subsubsection{Ferrous Metal Ions Chelating Ability}

The ferrous metal ion chelating activity of the AEHP was measured according to a literature protocol with a few modifications (Decker et al, 1990). The sample or an ethylene diamine tetraacetic acid (EDTA) solution (1 mL) was mixed with $50 \mu \mathrm{L}$ of ferrous chloride $(2 \mathrm{mM})$ and $0.2 \mathrm{~mL}$ of ferrozine $(5 \mathrm{mM})$. The mixtures were shaken well and allowed to stand for $10 \mathrm{~min}$ at room temperature, and the absorbance of the mixture was determined at $562 \mathrm{~nm}$. EDTA was included as the positive control. The ion-chelating activity was calculated as:

$$
\text { Chelating rate }(\%)=\left[1-\left(A_{1}-A_{2}\right) / A_{0}\right] \times 100 \%
$$

where $\mathrm{A}_{0}$ was the absorbance of the control without the sample, $\mathrm{A}_{1}$ was the absorbance in the presence of the sample, and $\mathrm{A}_{2}$ was the absorbance without ferrozine.

\subsubsection{SOD-like Activity}

The levels of SOD-like activity in the AEHP were measured with the SOD Assay Kit-WST according to the technical manual provided by Dojindo Molecular Technologies, Inc. Briefly, in a 96-well plate, $20 \mu \mathrm{L}$ of the sample solution was added to each sample and the well containing blank 2, and $20 \mu \mathrm{L}$ of double distilled water was added to the wells containing blank 1 and blank 3. Then, $200 \mu \mathrm{L}$ of the WST working solution was added to each well. After mixing, $20 \mu \mathrm{L}$ of the dilution buffer was added to the wells containing blank 2 and blank 3 , and $20 \mu \mathrm{L}$ of the enzyme working solution was added to each sample and the well containing blank 1 . The plate was incubated at $37^{\circ} \mathrm{C}$ for $20 \mathrm{~min}$, and the O.D. was determined at $450 \mathrm{~nm}$ using a microplate reader (BIO-RAD Model 550, USA). The SOD-like activity was calculated by the following equation:

$$
\text { SOD activity (inhibition rate \%) }=\left\{\left[\left(A_{\text {blank } 1}-A_{\text {blank } 3}\right)-\left(A_{\text {sample }}-A_{\text {blank } 2}\right)\right] /\left(A_{\text {blank } 1}-A_{\text {blank } 3}\right) \times 100\right.
$$

where $\mathrm{A}_{\text {blank } 1}, \mathrm{~A}_{\text {blank } 2}, \mathrm{~A}_{\text {blank } 3}$, and $\mathrm{A}_{\text {sample }}$ were the absorbances of blank 1, blank 2, blank 3 and the samples, respectively.

\subsection{Cell Culture}

The human colorectal cancer cell line, DLD-1, the human bladder cancer cell line, EJ-1, and the murine 
macrophage cell line, RAW 264.7, were purchased from the Riken Cell Bank (Tsukuba, Japan). The colorectal cancer cells were grown in RPMI 1640 (Roswell Park Memorial Institute-1640) medium. The other cells were grown in MEM medium (Minimum Essential Medium Eagle) containing 10\% foetal bovine serum, $100 \mathrm{U} / \mathrm{mL}$ penicillin and $100 \mu \mathrm{g} / \mathrm{mL}$ streptomycin. The cells were cultured at $37^{\circ} \mathrm{C}$ in a humidified $5 \% \mathrm{CO}_{2}$ atmosphere (ESPEC $\mathrm{CO}_{2}$ Incubator) for 2-3 days to reach the logarithmic phase for the following tests.

\subsection{Cell Viability Assay}

The inhibitory ability of the AEHP was measured on the human colorectal and bladder cancer cells. The cell cultures were exposed to various concentrations of the extracts for 24 and $48 \mathrm{~h}$ in Minimum Essential Medium (MEM) under anaerobic conditions at $37^{\circ} \mathrm{C}$. The effects of the AEHP on the anti-proliferation of DLD-1 and EJ-1 cells and the effect of the AEHP on the proliferation of the RAW 264.7 cells were estimated with the Cell Counting Kit-8 (CCK-8). The cells were cultured in a 96-well plate at a density of $5 \times 10^{4}$ cells $/ \mathrm{mL}$ at $37^{\circ} \mathrm{C}$ in a $5 \% \mathrm{CO}_{2}$ atmosphere for $24 \mathrm{~h}$. Next, $10 \mu \mathrm{L}$ of the AEHP solution, with concentrations of $0,6.25,12.5,25,50$, $100,200,400 \mu \mathrm{g} / \mathrm{mL}$, was added to the cell culture plates. The cell culture plates were cultured at $37^{\circ} \mathrm{C}$ in a $5 \%$ $\mathrm{CO}_{2}$ atmosphere for 24 and $48 \mathrm{~h}$. After this incubation, $10 \mu \mathrm{L}$ of the CCK-8 solution was added, and the plates were incubated at $37^{\circ} \mathrm{C}$ for $4 \mathrm{~h}$. The cell viability was determined by the O.D. at the wavelength of $450 \mathrm{~nm}$ with a microplate reader (BIO-RAD Model 550). The data were expressed as percentages of the control.

\subsection{Statistical Analysis}

The experiments were repeated three times, and each was arranged in three groups in parallel. The experimental results were given as the means \pm S.D. of three replicate measurements. Tests of significant difference were determined by Student's t-test analysis at $\mathrm{P}=0.05$ or independent sample t-test $(\mathrm{P}=0.05)$.

\section{Results and Discussion}

\subsection{Static and Dynamic Adsorption / Desorption Tests}

\section{$3.1 .1 \mathrm{pH}$ and Temperature}

Table 1. The adsorption and degradation ratios of anthocyanins at different $\mathrm{pHs}$ (Static test data)

\begin{tabular}{lcccccccccc}
\hline & \multirow{2}{*}{$\mathrm{A}_{536 \mathrm{~nm}}$} & \multicolumn{10}{c}{$\mathrm{pH}$} \\
\cline { 3 - 11 } & & 1 & 2 & 3 & 4 & 5 & 6 & 7 & 8 & 9 \\
\hline Adsorption ratio (\%) & \multirow{2}{*}{0.54} & 30.28 & 34.31 & 25.61 & 14.86 & 6.59 & 1.28 & 0.85 & 0.84 & 0.65 \\
Degradation ratio (\%) & & 66.59 & 51.32 & 45.29 & 34.70 & 23.36 & 12.69 & 11.75 & 10.71 & 6.65 \\
\hline
\end{tabular}

Table 2. The yields of the AEHP and anthocyanin contents at different $\mathrm{pHs}$ (dynamic test data)

\begin{tabular}{llll}
\hline & \multicolumn{3}{c}{$\mathrm{pH}$} \\
\cline { 2 - 4 } & 2 & 3 & 4 \\
\hline AEHP yield (mg) & $84.00 \pm 2.20$ & $76.00 \pm 1.90$ & $54.00 \pm 3.50$ \\
Anthocyanin content (mg) & $24.51 \pm 1.06$ & $24.97 \pm 1.19$ & $12.93 \pm 0.74$ \\
Anthocyanin concentration (\%) & $29.22 \pm 2.05$ & $32.83 \pm 2.35$ & $23.94 \pm 2.81$ \\
\hline
\end{tabular}

As shown in Table 1, the maximum absorption wavelengths were all $536 \mathrm{~nm}$ from $\mathrm{pH} 1$ to 9 except $\mathrm{pH} 2$ and 3 . At pH 2 and 3, the maximum absorption wavelengths were 534.5 and $535.5 \mathrm{~nm}$, respectively. When the initial absorbance of the sample was 0.54 at $536 \mathrm{~nm}$, the resin exhibited a stronger adsorption capacity and higher degradation ratio from $\mathrm{pH} 1$ to 4 than from $\mathrm{pH} 5$ to 9 . According to the above results, the dynamic tests were investigated at $\mathrm{pH} 2,3$ and 4 . Finally, the optimum $\mathrm{pH}$ was determined to be 3 (Table 2).

Next, the optimum temperature was evaluated by static tests at $\mathrm{pH} 3$. The results showed that the adsorption capacity of the resin increased, and the degradation ratio of anthocyanins decreased as the temperature decreased (Zhao et al., 2011). Therefore, the optimum temperature was $25^{\circ} \mathrm{C}$.

\subsubsection{Adsorption Kinetics on SP825 Resin}

The following kinetic models were adopted to describe the adsorption process: pseudo-first-order, pseudo-second-order and intra-particle diffusion kinetic models. The equations of the three models are the 
following, respectively:

$$
\begin{gathered}
\lg \left(q_{e}-q_{t}\right)=-\left(k_{1} / 2.303\right) t+\lg q_{e} \\
t / q_{t}=\left(1 / q_{e}\right) t+1 / k_{2} q_{e}{ }^{2} \\
q_{t}=k_{i d} t^{1 / 2}+c
\end{gathered}
$$

where $\mathrm{q}_{\mathrm{e}}$ and $\mathrm{q}_{\mathrm{t}}$ were the adsorption capacity at equilibrium and at any time $\mathrm{t}(\mathrm{mg} / \mathrm{g}$ dry resin), respectively. The parameters $\mathrm{k}_{1}\left(\mathrm{~min}^{-1}\right), \mathrm{k}_{2}(\mathrm{~g} /[\mathrm{mg} \cdot \mathrm{min}])$ and $\mathrm{k}_{\mathrm{id}}\left(\mathrm{mg} /\left[\mathrm{g} \cdot \mathrm{min}^{1 / 2}\right]\right)$ were the apparent rate constants of the pseudo-first-order, pseudo-second-order and intra-particle diffusion models for the adsorption process, respectively. C ( $\mathrm{mg} / \mathrm{g})$, which was the constant, represents the boundary layer thickness. Plotting $\lg \left(\mathrm{q}_{\mathrm{e}}-\mathrm{q}_{\mathrm{t}}\right)$ against $t$ produced straight lines $\left(\mathrm{R}^{2}=0.4653\right)$ for Equation (11). Plotting $\mathrm{t} / \mathrm{q}_{\mathrm{t}}$ against $\mathrm{t}$ produced straight lines $\left(\mathrm{R}^{2}=0.9919, \mathrm{y}=0.1148 \mathrm{x}+10.526\right)$ for Equation (12). Plotting $\mathrm{q}_{\mathrm{t}}$ versus $\mathrm{t}^{1 / 2}$ produced straight lines $\left(\mathrm{R}^{2}=\right.$ 0.9704) for equation (13). The pseudo-second-order kinetic model was suitable for describing the whole adsorption process of the anthocyanins on the SP825 resin. Furthermore, the finding implied that concentrations of both the adsorbate and adsorbent were involved in the rate-determining step in the adsorption process, which might be chemical adsorption or chemisorption (Liu et al., 2010).

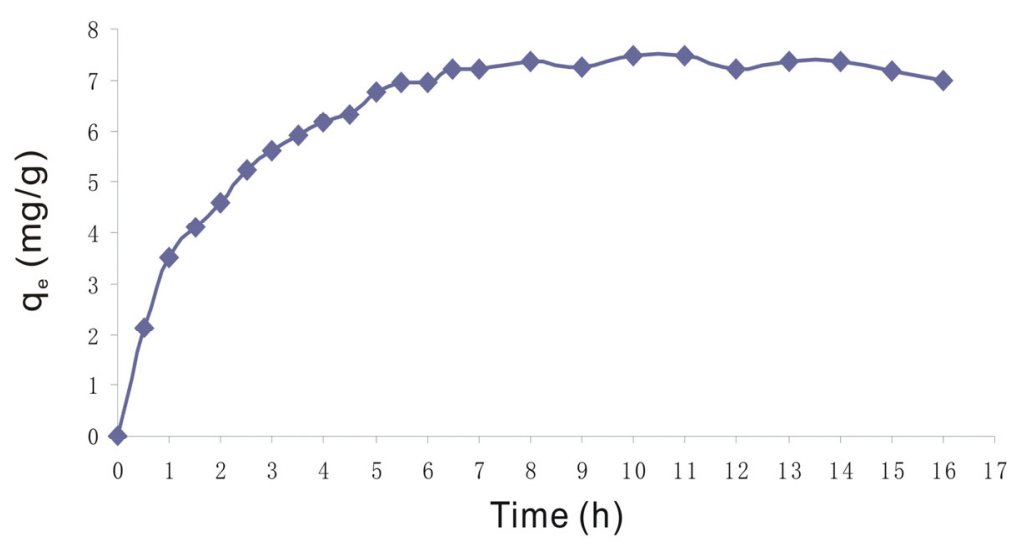

Figure 1. Adsorption kinetic curves for anthocyanins on the SP825 resin at $25^{\circ} \mathrm{C}$

As shown in Figure 1 , at $25^{\circ} \mathrm{C}$, the absorption kinetic curve of the anthocyanins on the SP825 resin was obtained. The absorption capacity increased with increased time. The absorption reached equilibrium after $8 \mathrm{~h}\left(\mathrm{q}_{\mathrm{e}}=8.71\right.$ $\mathrm{mg} / \mathrm{g}$ ).

3.1.3 Adsorption Isotherms and Thermodynamics on the SP825 Resin

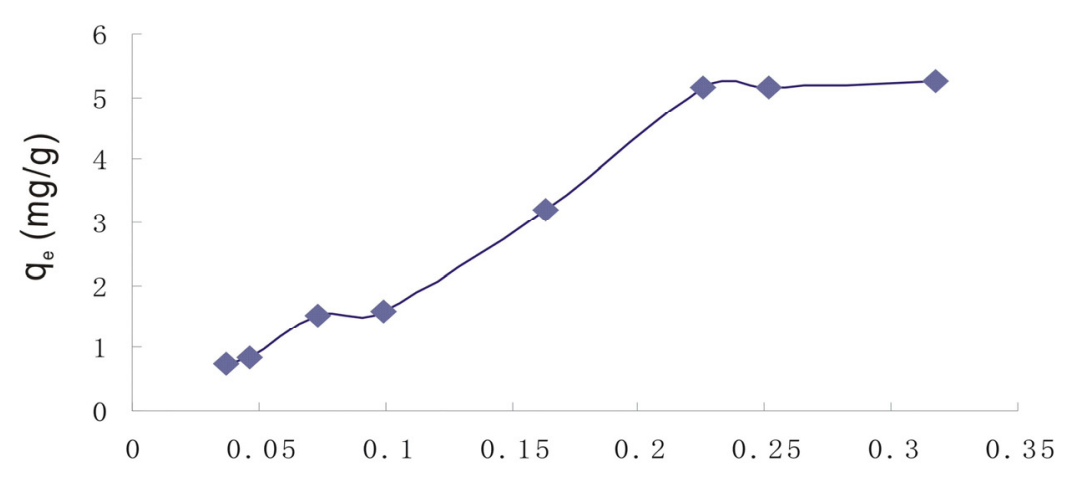

The initial concentration of anthocyanins $(\mathrm{mg} / \mathrm{mL})$

Figure 2. Adsorption isotherms for anthocyanins on the SP825 resin at $25^{\circ} \mathrm{C}$

As shown in Figure 2, the equilibrium adsorption isotherm was constructed at $25^{\circ} \mathrm{C}$. The initial concentrations of the anthocyanins were $0.037,0.047,0.073,0.099,0.163,0.225,0.252$, and $0.318 \mathrm{mg} / \mathrm{mL}$, respectively. The 
absorption capacity increased as the concentration increased. Moreover, the resin reached the saturation plateau after $8 \mathrm{~h}$ in three samples, which contained $0.225,0.252$, and $0.318 \mathrm{mg} / \mathrm{mL}$ anthocyanins. Thus, in theory, they were selected as the initial concentrations to extract.

The equilibrium data were analysed following the Langmuir and Freundlich model. The Langmuir equation $\mathrm{C}_{\mathrm{e}} /$ $\mathrm{q}_{\mathrm{e}}=\mathrm{C}_{\mathrm{e}} / \mathrm{q}_{\mathrm{m}}+(1 / \mathrm{K}) \mathrm{q}_{\mathrm{m}}$ was converted to the linearised form with $\mathrm{C}_{\mathrm{e}}$ and $\mathrm{C}_{\mathrm{e}} / \mathrm{q}_{\mathrm{e}}$ as independent variables and $\mathrm{R}^{2}$ $=0.7541$. A linearised version of the Freundlich equation $\mathrm{q}_{\mathrm{e}}=\mathrm{K} \mathrm{C}_{\mathrm{e}}^{1 / \mathrm{n}}$ can be written as equation $\log \mathrm{q}_{\mathrm{e}}=\log \mathrm{K}+$ $(1 / n) \log C_{e}$, with $K$ and $n$ obtained from the intercept and slope $(K=23.8, n=1)$, respectively, and $R^{2}=0.9672$. In these equations, $\mathrm{q}_{\mathrm{e}}$ was the adsorption capacity at equilibrium ( $\mathrm{mg} / \mathrm{g}$ dry resin), $\mathrm{C}_{\mathrm{e}}$ was the concentration of anthocyanins at equilibrium $\left(\mathrm{mg} / \mathrm{mL}\right.$ ), and $\mathrm{q}_{\mathrm{m}}$ was the maximum adsorption capacity ( $\mathrm{mg} / \mathrm{g}$ dry resin).

The Langmuir and Freundlich equations are used to reveal the linearity fit and to describe the equilibrated relationship between the concentrations of the adsorbate in the fluid phase and the adsorbent at a given temperature (Liu et al., 2010). The absorption process is consistent with the Freundlich model $(n=1)$. Generally, adsorption is difficult when $\mathrm{n}$ is less than 0.5.

\subsubsection{Dilution Multiple of Sample Solution}

The theoretical concentrations of the samples were obtained from isothermal adsorption experiments at a natural $\mathrm{pH}$. In the dynamic tests, the volumes of added distilled water were 1, 2, 3 and 4 sample volumes, and the dilution multiples were 2, 3, 4 and 5, respectively. The anthocyanin contents of the AEHP were $2.5 \pm 0.34 \mathrm{mg}$, $3.3 \pm 0.48 \mathrm{mg}, 2.2 \pm 0.09 \mathrm{mg}$ and $0.9 \pm 0.23 \mathrm{mg}$, respectively. The optimum dilution multiple of the sample was 3 .

\subsubsection{The Concentration of Ethanol Eluting Agent}

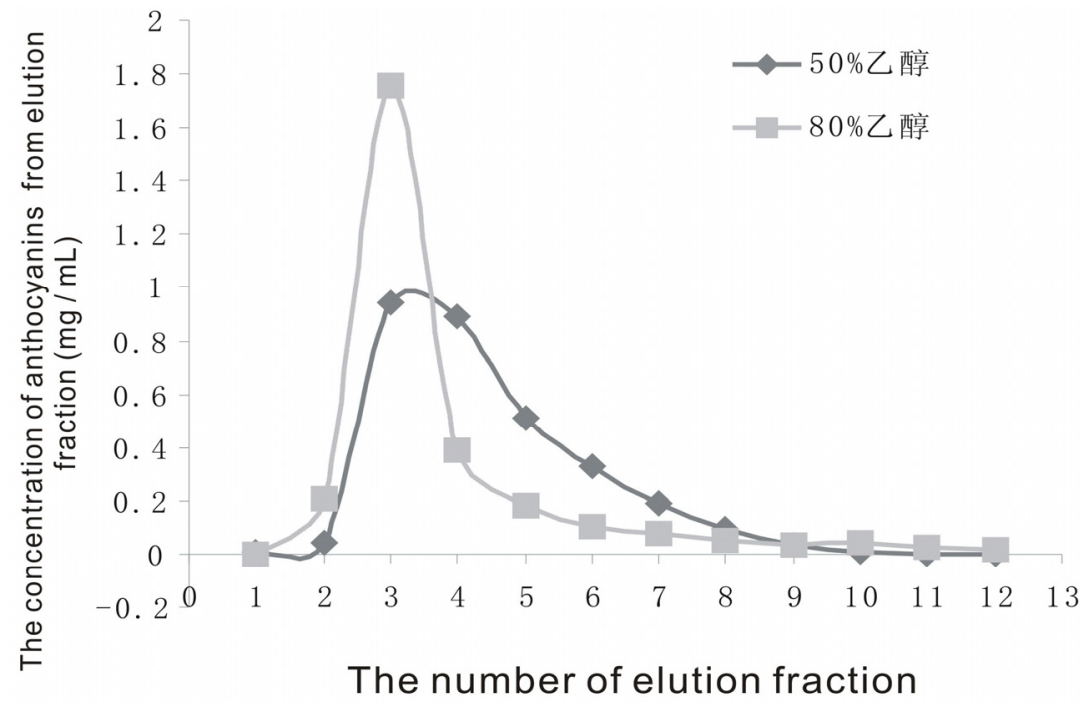

Figure 3. Ethanol elution curves for anthocyanins in the $\mathrm{SP} 825$ resin at $25^{\circ} \mathrm{C}$

As shown in Figure 3, the volume of every elution fraction was $2.5 \mathrm{~mL}$. The horizontal coordinate expressed the numbers of the elution fractions over time. The ethanol eluting agent concentrations were $50 \%$ and $80 \%$. The elution fraction volume was $2.5 \mathrm{~mL}$. The elution curve was drawn according to the anthocyanin concentration of the fraction. Figure 3 showed that the anthocyanins were more concentrated with the $80 \%$ ethanol elution agent, meaning that the sample volume became smaller and the rotary evaporating time became shorter. Finally, the loss of the anthocyanins decreased in the extraction process. Thus $80 \%$ ethanol was found to be able to elute most of the anthocyanins adsorbed by the resin (Liu et al., 2004).

\subsection{Anthocyanins and Polyphenol Contents and E of AEHP}

A total of $1000 \mathrm{~g}$ of $H$. polyrhizus fresh fruit (both peel and pulp) contained $658 \mathrm{mg}$ of anthocyanins and could be made into $1.5 \mathrm{~g}$ of the AEHP, which contained $520 \mathrm{mg}$ of anthocyanins. Thus, $79 \%$ of the anthocyanins could be extracted from the fresh fruit.

In the following experiments, we used an AEHP containing 29\% anthocyanins and $31.3 \%$ polyphenol, and its $\mathrm{E}$ was 76.23. According to the International colour units (ICU) standard, $E=150$ is equivalent to 100000 ICU. The 
E of the AEHP was 76.23, equivalent to 50820 ICU. The E of the AEHP was 19 times that of the food additive Radish red GB6718-86. Thus, the AEHP has a strong potential as a natural colorant.

\subsection{Antioxidant Abilities of AEHP}

Table 3. $\mathrm{EC}_{50}$ value and anthocyanin and polyphenol contents at the $\mathrm{EC}_{50}$ value

\begin{tabular}{llllll}
\hline $\begin{array}{l}\text { Antioxidant } \\
\text { assays }\end{array}$ & $\begin{array}{l}\mathrm{EC}_{50} \text { of positive } \\
\text { control }(\mathrm{mg} / \mathrm{mL})\end{array}$ & $\begin{array}{l}\mathrm{EC}_{50} \text { of AEHP } \\
(\mathrm{mg} / \mathrm{mL})\end{array}$ & $\begin{array}{l}\text { Anthocyanin } \\
\text { content of AEHP } \\
(\mathrm{mg} / \mathrm{mL})\end{array}$ & $\begin{array}{l}\text { Polyphenol } \\
\text { content of AEHP } \\
(\mathrm{mg} / \mathrm{mL})\end{array}$ & Positive control \\
\hline $\begin{array}{l}\text { DPPH·radical } \\
\text { scavenging } \\
\text { activity }\end{array}$ & 0.290 & 0.040 & 0.012 & 0.013 & Ascorbic acid \\
$\begin{array}{l}\text { ABTS radical } \\
\text { scavenging }\end{array}$ & 0.840 & 0.170 & 0.049 & 0.053 & Ascorbic acid \\
$\begin{array}{l}\text { activity } \\
\begin{array}{l}\text { Ferrous metal } \\
\text { ions chelating }\end{array}\end{array}$ & 1.260 & 0.540 & 0.157 & 1.725 & EDTA \\
$\begin{array}{l}\text { activity } \\
\text { SOD }\end{array}$ & 0.170 & 0.049 & 0.053 & - \\
\hline
\end{tabular}

As shown in Table 3, the antioxidant abilities of the AEHP were analysed. The values of $\mathrm{EC}_{50}$ were obtained by interpolation from linear regression analysis. The values of $\mathrm{EC}_{50}$ were the effective concentrations when $50 \%$ radicals were scavenged.

\subsubsection{DPPH·Radical Scavenging Activity}

The DPPH-approach is simple and widely applied to the measurement of the antioxidant activity of polyphenolics and colourants (Lichen Wu et al., 2006). With ascorbic acid as a positive control, the $\mathrm{EC}_{50}$ values of ascorbic acid and the AEHP were $290 \mu \mathrm{g} / \mathrm{mL}\left(\mathrm{R}^{2}=1\right)$ and $40 \mu \mathrm{g} / \mathrm{mL}\left(\mathrm{R}^{2}=0.96\right)$, respectively. The consumption of AEHP was $14.3 \%$ of ascorbic acid scavenging $50 \%$ of the radicals. Compared with the results of the anthocyanin-rich extract from acai at $50 \mu \mathrm{g} / \mathrm{mL}$ quenching $39.6 \%$ of the radicals (Hogan et al., 2010), AEHP had a better efficiency in the DPPH radical scavenging activity. This finding suggested that the AEHP might have biomedical applications in reducing body oxidative stress and the deteriorating situation arising from the elevation of various reactive oxygen species (ROS).

\subsubsection{ABTS Radical Scavenging Activity}

Anthocyanins are water-soluble pigments (Benoit, 2004). The ABTS method is suitable for not only water-soluble antioxidants but also lipid-soluble antioxidants. The ABTS approach has been suggested to be better for evaluating the antioxidant activity of phenolic phytochemicals than the DPPH radical scavenging assay (Wu et al., 2006). With ascorbic acid as a positive control, the $\mathrm{EC}_{50}$ values of ascorbic acid and AEHP were 840 $\mu \mathrm{g} / \mathrm{mL}\left(\mathrm{R}^{2}=0.9997\right)$ and $170 \mu \mathrm{g} / \mathrm{mL}\left(\mathrm{R}^{2}=0.9527\right)$, respectively. The consumption of AEHP was $20 \%$ of ascorbic acid scavenging $50 \%$ of the radicals.

\subsubsection{Hydroxyl Radical Scavenging Activity}

The hydroxyl radical is considered the most reactive and poisonous free radical in organisms because it can non-specifically oxidise all classes of biological macromolecules, including lipids, proteins, and nucleic acids (Xiong et al., 2011). When the dose was $0.156 \mathrm{mg} / \mathrm{mL}$, the hydroxyl scavenging ratios of the positive control (ascorbic acid) and AEHP were $6.67 \%$ and $100 \%$, respectively. The hydroxyl radical scavenging ability of the AEHP was 15 times that of ascorbic acid.

\subsubsection{Reducing Power}

Table 4. Absorbance at $700 \mathrm{~nm}$

\begin{tabular}{lllllll}
\hline Dose $(\mathrm{mg} / \mathrm{mL})$ & 0.156 & 0.313 & 0.625 & 1.25 & 2.5 & 5 \\
\hline Ascorbic acid & $0.853 \pm 0.015$ & $1.074 \pm 0.039$ & $1.490 \pm 0.011$ & $1.579 \pm 0.010$ & $1.611 \pm 0.007$ & $1.668 \pm 0.001$ \\
AEHP & $0.111 \pm 0.000$ & $0.169 \pm 0.010$ & $0.619 \pm 0.020$ & $1.242 \pm 0.010$ & $1.643 \pm 0.000$ & $1.661 \pm 0.000$ \\
\hline
\end{tabular}


The reducing power shows the electron-donating activity. A strong reducing power indicates a good electronic supply capacity. It may be used as an indicator of potential antioxidant activity (Wang et al., 2008). Table 4 presents the reducing power of the AEHP and the positive control (ascorbic acid). A great O.D. at $700 \mathrm{~nm}$ showed a great reduction force and suggested that the AEHP has a dose-dependent reducing power. At doses of less than $2.5 \mathrm{mg} / \mathrm{mL}$, the reducing power of the AEHP increased at a faster speed than that of ascorbic acid. At doses of greater than $2.5 \mathrm{mg} / \mathrm{mL}$, the reducing powers of the AEHP and ascorbic acid were approximately the same.

\subsubsection{Ferrous Metal Ion Chelating Activity}

The transition metal can be used as a catalyst to produce the initiated few free radicals that mediate the oxidation chain reaction in biological and food systems. The concentration of the transition metal can be reduced because of the metal chelating ability. In this study, the AEHP was compared with a positive control (EDTA). The chelating action of the AEHP on the ferrous ions increased with the increasing concentration of the AEHP. The $\mathrm{EC}_{50}$ values of EDTA and the AEHP were $1260 \mu \mathrm{g} / \mathrm{mL}\left(\mathrm{R}^{2}=0.99\right)$ and $540 \mu \mathrm{g} / \mathrm{mL}\left(\mathrm{R}^{2}=0.96\right)$, respectively. The consumption of the AEHP was less than $50 \%$ of EDTA chelating $50 \%$ of the ferrous metal ions. EDTA chelated $59.16 \pm 4.62 \%$ of the ferrous ions at $1.25 \mathrm{mg} / \mathrm{mL}$, and the AEHP showed a stronger chelating ability $(89.50 \pm 1.10 \%)$.

\subsubsection{SOD-Like Activity of AEHP}

All organisms have a complex antioxidant defence system, including antioxidant enzymes, such as SOD and catalase (Shi et al., 2013). The AEHP demonstrated a strong SOD-like activity with its increased concentration, and its SOD-like activity was $100 \%$ at $1.25 \mathrm{mg} / \mathrm{mL}$. The anthocyanin and polyphenol contents were 0.363 and $0.391 \mathrm{mg} / \mathrm{mL}$, respectively.

\subsection{Anticancer Ability of AEHP}

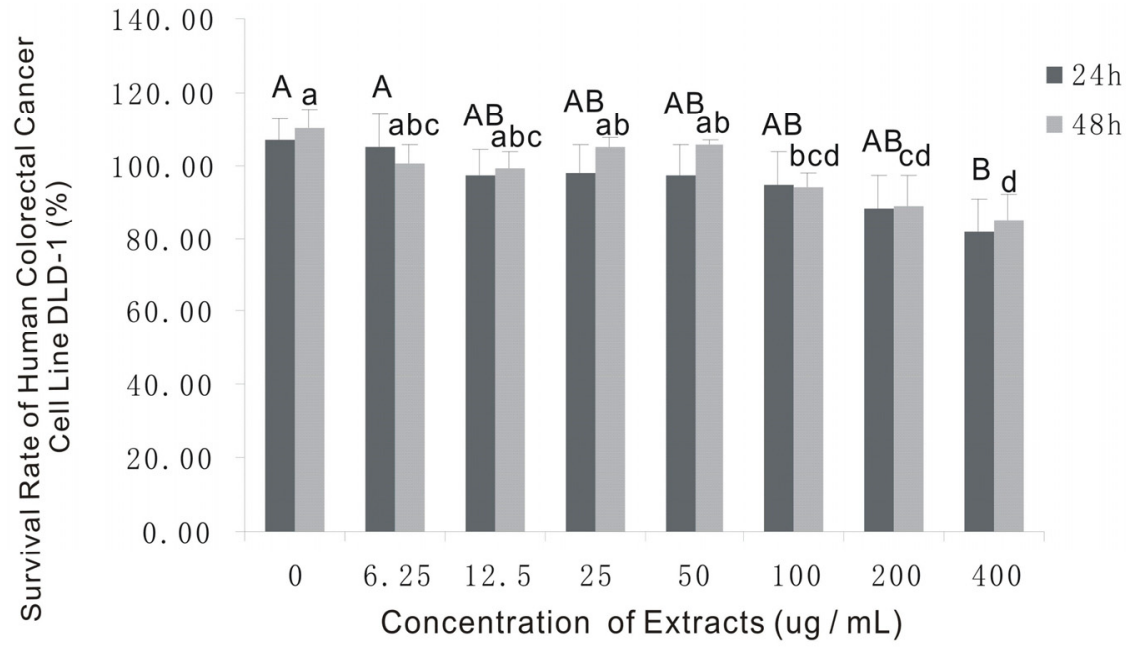

Figure 4. The effect of the AEHP on the survival ratios of human colorectal cancer cells, DLD-1

In Figure 4, the capital letter group and the small letter group represent significant differences in the cancer cell survival ratios, depending on the AEHP treatment at different concentrations, after 24 and $48 \mathrm{~h}$, respectively. The same letters represented no significant difference in the groups, and different letters represented the opposite. As shown in Figure 4, the AEHP could inhibit the proliferation of the human colorectal cancer cell line, DLD-1. The DLD-1 cell survival ratio showed significant differences under the AEHP concentrations between 0 and $400 \mu \mathrm{g} /$ $\mathrm{mL}$ after $24 \mathrm{~h}(\mathrm{p}<0.05)$. Moreover, the DLD-1 cell survival ratios presented significant differences between the concentrations of 100, 200 and $400 \mu \mathrm{g} / \mathrm{mL}$ and $0 \mu \mathrm{g} / \mathrm{mL}$ AEHP after $48 \mathrm{~h}(\mathrm{p}<0.05)$. 
Table 5. Time and concentration double factors analysis results of AEHP on human colorectal cancer cells

\begin{tabular}{llll}
\hline Impact factors & Df & F & Siq \\
\hline Concentration & 7 & 8.312 & 0.000 \\
Time & 1 & 1.506 & 0.229 \\
Concentration $\times$ Time & 7 & 0.512 & 0.819 \\
\hline
\end{tabular}

As Table 5 shows, the concentration was the key factor to inhibit the growth of the cancer cells, but time was not. Otherwise, the AEHP could not inhibit the proliferation of the human bladder cancer cell line EJ-1. These results indicated that biological extract might have a different inhibitory mechanism against the proliferation of cancer cell, suggesting that the specificity of the bioactive components should be studied.

\subsection{Macrophage Proliferation by AEHP}

The AEHP shows a proliferation effect on the macrophage RAW 264.7 cells. After treatments with 200 and 400 $\mu \mathrm{g} / \mathrm{mL}$ AEHP for $24 \mathrm{~h}$, the macrophage survival ratios were $168.82 \%$ and $178.12 \%$, respectively. However, the macrophage survival ratios were decreased by $32.26 \%$ and $26.65 \%$, respectively, after $48 \mathrm{~h}$. AEHP affected macrophages growth in a dose-dependent and time-dependent manner.

\section{Conclusions}

Using a dilution multiple of 3 and $\mathrm{pH}$ of 3, Purple pitaya (H. polyrhizus) juice were filtered through 300 mesh gauze. Then diatomite powders were placed into the centrifuge. Next, the supernatant, $3 \mathrm{BV}$ distilled water and 3 BV ethanol eluting agent ( $80 \%$ ) were passed through the resin column at $3 \mathrm{~mL} / \mathrm{min}$ in that order. The collected elution liquid was rotated and evaporated and then freeze-dried. We extracted $79 \%$ of the anthocyanins from the fresh fruits. In addition, the AEHP revealed strong DPPH radical scavenging activity, ABTS radical scavenging activity, hydroxyl radical scavenging, reducing power, ferrous metal ion chelating activity and SOD-like activity. Moreover, the AEHP inhibited the proliferation of cancer cells and promoted the proliferation of the macrophage cells. Further studies are in progress on the characterisation and functional effects of the anthocyanins from the AEHP and their activation mechanism.

\section{Acknowledgments}

This research project was financially supported by the Japan student services organization (JASSO) and the short-term student exchange programs between the University of Tsukuba of Japan and Yunnan University of China.

\section{References}

Benoit, S. (2004). Determination of pigments in vegetables. Journal of Chromatography A, 1054(1-2), 217-226. http://dx.doi.org/10.1016/j.chroma.2004.05.105

Blois, M. S. (1958). Antioxidant determinations by the use of a stable free radical. Nature, 181, 1199-1200. http://dx.doi.org/10.1038/1811199a0

Chou, P. H., Matsui, S., Misaki, K., \& Matsuda, T. (2007). Isolation and identification of xenobiotic aryl hydrocarbon receptor ligands in dyeing wastewater. Environmental Science and Technology, 41(2), 652-657. http://dx.doi.org/10.1021/es061500g

Cooke, D., Steward, W. P., Gescher, A. J., \& Marczylo, T. (2005). Anthocyans from fruits and vegetables-Does bright colour signal cancer chemopreventive activity. European Journal of Cancer, 41(13), 1931-1940. http://dx.doi.org/10.1016/j.ejca.2005.06.009

Decker E. A., \& Welch B. (1990). Role of ferritin as a Lipid oxidation catalyst in muscle food. Journal of Agricultural and Food Chemistry, 38(3), 674-677. http://dx.doi.org/10.1021/jf00093a019

Fan, M. H., \& Xu, S. Y. (2008). Adsorption and desorption properties of macroreticular resins for salidroside from Rhodiola sachalinensis A. Bor. Separation and Purification Technology, 61(2), 211-216. http://dx.doi.org/10.1016/j.seppur.2007.07.046

He, J., \& Giusti, M. M. (2010). Anthocyanins: Natural Colorants with Health-Promoting Properties. Food Science and Technology, 1, 163-187. http://dx.doi.org/10.1146/annurev.food.080708.100754

Hogan, S., Chung, H., Zhang, L., Li, J. R., Lee, Y. W., Dai, Y. M., \& Zhou, K. Q. (2010). Antiproliferative and antioxidant properties of anthocyanin-rich extract from acai. Food Chemistry, 118, 208-214. 
http://dx.doi.org/10.1016/j.foodchem.2009.04.099

Liu, X. M., Xiao, G. S., Chen, W. D., Xu, Y. J., \& Wu, J. J. (2004). Quantification and Purification of Mulberry Anthocyanins with Macroporous Resins. Journal of Biomedicine and Biotechnology, 2004(5), 326-331. http://dx.doi.org/10.1155/S1110724304403052

Liu, Y. F., Liu, J. X., Chen, X. F., Liu, Y. W., \& Di, D. L. (2010). Preparative separation and purification of lycopene from tomato skins extracts by macroporous adsorption resins. Food Chemistry, 123, 1027-1034. http://dx.doi.org/10.1016/j.foodchem.2010.05.055

Mau, J. L., Lin, H. C., \& Song, S. F. (2002). Antioxidant properties of several specialty mushrooms. Food Research International, 35, 519-526. http://dx.doi.org/10.1016/S0963-9969(01)00150-8

Nicholas, S., \& Cumbes, Q. J. (1989). Hydroxyl radical scavenging activity of compatible solutes. Phytochemistry, 28(4), 1057-1060. http://dx.doi.org/10.1016/0031-9422(89)80182-7

Pergola, C., Rossi, A., Dugo, P., Cuzzocrea, S., \& Sautebin, L. (2006). Inhibition of nitric oxide biosynthesis by anthocyanins fraction of blackberry extract. Nitric Oxide, 15(1), 30-39. http://dx.doi.org/10.1016/j.niox.2005.10.003

Shi, M., Zhang, Z. Y., Yang, Y. N. (2013). Antioxidant and immunoregulatory activity of Ganoderma lucidum $\begin{array}{lllll}\text { polysaccharide (GLP). } & \text { Carbohydrate } & \text { Polymers, } & \text { 95, }\end{array}$ http://dx.doi.org/10.1016/j.carbpol.2013.02.081

Smith, M., Marley, K., Seigler, D., Singletary, K., \& Meline, B. B. (2000). Bioactive properties of wild blueberry fruits. Journal of Food Science, 65, 352-356. http://dx.doi.org/10.1111/j.1365-2621.2000.tb16006.x

Trishna D, Pyo-Jam P, Narayan C. D. N., Nadira, B. S., Hee, W. P., \& Beong, O. L. (2011). Antioxidant activity of Gardenia jasminoides Ellis fruit extracts. Food Chemistry, 128, 697-703. http://dx.doi.org/10.1016/j.foodchem.2011.03.090

Wang, C. J., Wang, J. M., Lin, W. L., Chu, C., Chou, F. P., \& Tseng, T. H. (2000). Protective effect of Hibiscus anthocyanins against tert-butyl hydroperoxide-induced hepatic toxicity in rats. Food and Chemical Toxicology, 38(5), 411-416. http://dx.doi.org/10.1016/S0278-6915(00)00011-9

Wang, H. Y., Zhao, M. M., Yang, B., Jiang, Y. M., \& Rao, G. H. (2008). Identification of polyphenols in tobacco leaf and their antioxidant and antimicrobial activities. Food Chemistry, 107, 1399-1406. http://dx.doi.org/10.1016/j.foodchem.2007.09.068

Wang, L. S., \& Stoner, G. D. (2008). Anthocyanins and their role in cancer prevention. Cancer Letters, 269(2), 281-290. http://dx.doi.org/10.1016/j.canlet.2008.05.020

Wu, L. C., Hsu, H. W., Chen, Y. C., Chiu, C. C., Lin, Y. I., \& Ho, J. A. (2006). Antioxidant and antiproliferative activities of red pitaya. Food Chemistry, 95, 319-327. http://dx.doi.org/10.1016/j.foodchem.2005.01.002

Wu, X. L., \& Prior, R. L. (2005). Identification and characterization of anthocyanins by high-performance liquid chromatography-electrospray ionization-tandem mass spectrometry in common foods in the United States: Vegetable, nuts, and grains. Journal of Agricultural and Food Chemistry, 53(8), 3101-3113. http://dx.doi.org/10.1021/jf0478861

Xiong, S. L., Li, A. L., Huang, N., Lu, F., \& Hou, D. B. (2011). Antioxidant and immunoregulatory activity of different polysaccharide fractions from tuber of Ophiopogon japonicus. Carbohydrate Polymers, 86, 1273-1280. http://dx.doi.org/10.1016/j.carbpol.2011.06.025

Yang, Z. D., \& \& Zhai, W. W. (2010). Identification and antioxidant activity of anthocyanins extracted from the seed and cob of purple corn (Zea mays L.). Innovative Food Science and Emerging Technologies, 11, 169-176. http://dx.doi.org/10.1016/j.ifset.2009.08.012

Yen, G. C., \& Chen, H. Y. (1995). Antioxidant activity of various tea extract in relation to their antimutagenicity. Journal of Agricultural and Food Chemistry, 43(1), 27-32. http://dx.doi.org/10.1021/jf00049a007

Zhao, Z. Y., Dong, L. L., Wu, Y. L., \& Lin, F. (2011). Preliminary separation and purification of rutin and quercetin from Euonymus alatus (Thunb). Siebold extracts by macroporous resins. Food and Bioproducts Processing, 89(4), 266-272. http://dx.doi.org/10.1016/j.fbp.2010.11.001 